Title: Building and Evaluating Juvenile Collections in Academic Libraries

Author: Virginia Kay Williams, M.L.S., S.L.I.S., J.D., Acquisitions Librarian, Ablah Library, Wichita State University,1845 Fairmount St. Box 68, Wichita, KS 67260-0068, ginger.williams@wichita.edu

Abstract: Although many college and university libraries support teacher education programs, relatively little attention has been paid to developing juvenile literature collections that support these programs. This paper discusses needs of education students and characteristics of juvenile literature which academic librarians should consider when developing collections. It examines standard tools for selecting children's and young adult materials and analyzes their usefulness for building collections that support teacher preparation programs. Finally, it provides practical advice for evaluating juvenile collections and selecting materials to fill gaps in support for teacher preparation programs in mathematics, art, and other subjects.

Keywords: Juvenile literature, children's literature, young adult literature, teacher education, academic libraries, collection development, collection evaluation.

This manuscript has not been published elsewhere and has not been submitted simultaneously for publication elsewhere. 


\title{
Building and Evaluating Juvenile Collections in Academic Libraries
}

\author{
Virginia K. Williams
}

\begin{abstract}
Although many college and university libraries support teacher education programs, relatively little attention has been paid to developing juvenile literature collections that support these programs. This paper discusses needs of education students and characteristics of juvenile literature which academic librarians should consider when developing collections. It examines standard tools for selecting children’s and young adult materials and analyzes their usefulness for building collections that support teacher preparation programs. Finally, it provides practical advice for evaluating juvenile collections and selecting materials to fill gaps in support for teacher preparation programs in mathematics, art, and other subjects.
\end{abstract}

KEYWORDS. Juvenile literature, children's literature, young adult literature, teacher education, academic libraries, collection development, collection evaluation.

Teacher education programs are common in colleges and universities; there are over six hundred nationally accredited teacher education programs in the United States (National Council for Accreditation of Teacher Education 2009). Many academic libraries collect juvenile literature to support teacher education programs. But while schools of library and information science often offer courses in juvenile literature, those courses are targeted at future public and school librarians, not at future academic librarians. New academic librarians charged with developing a juvenile collections may have fond memories of favorite childhood books like The Very Hungry Caterpillar or Charlie and the Chocolate Factory, but they need an understanding of how education students use juvenile literature, the characteristics of juvenile literature, and the standard tools available for selecting and evaluating children's and young adult collections. 


\section{LITERATURE REVIEW}

Although much has been written about developing collections for children and young adults, little information is available on developing and evaluating juvenile collections for academic library users. Two articles by new academic librarians, Hirsch (2006) and Bay (2001), both discuss the frustration of being assigned responsibility for juvenile literature with no background in the subject and efforts to learn enough about children's literature to manage juvenile collections. Both recommend some good strategies for novices, such as consulting with education faculty and elementary teachers. Each mentions a few good selection tools, including School Library Journal. Bay’s almost wistful comment that “[t]here are undoubtedly more sources of information ...” (Bay 2001) inspired the author, a former school librarian familiar with both juvenile literature and the needs of education students, to draft this paper as a crash course for librarians assigned to manage juvenile collections in academic libraries.

Resources on managing curriculum materials centers seem an obvious place to find help in selecting and evaluating the academic library’s juvenile collection. Juvenile materials should be included in curriculum materials centers (Association of College and Research Libraries 2009), but, as Osa’s (2003) article on developing curriculum materials centers explains, the curriculum materials center includes a wide variety of materials to support teacher education programs, so papers and books on curriculum materials centers seldom devote much space to juvenile literature. Lare’s (2004) excellent guide on acquiring curriculum materials excludes children's and young adult literature because he considers acquiring juvenile books relatively straightforward. Uhl's (2007) recent article on curriculum material centers explains why children’s literature should be included and gives a few examples of titles that support math, science, and social studies. These documents and articles on curriculum material centers provide valuable information on the needs of education students, but have limited information on collecting and evaluating children’s materials.

Other articles provide insights on how juvenile collections are used in academic libraries or concern special collections of children’s literature. In their article on reader’s advisory services, Rice-Lively and Immroth (1993) discussed some of the ways college students and faculty use children's literature and 
resources librarians can provide to help them find materials for specific needs. Nevins (1994) describes how a user satisfaction survey and list-checking in response to student dissatisfaction with the children's literature collection revealed that the dissatisfaction resulted primarily from difficulty finding materials needed for specific purposes. Unfortunately Nevins does not provide a list of survey questions, but her summary of responses provides some clues for constructing a similar user satisfaction survey. Frierson-Adams’ (2001) paper on cataloging and arranging a children's literature collection also includes information from a survey of academic libraries about collection users. Several articles discuss special collections of children's materials in academic libraries; for example, Bingham (2004) describes how a large gift prompted the University of Washington's librarians to evaluate existing holdings, seek additional donations, and raise the collecting level of American Indian children’s literature.

Although the literature review focused on juvenile literature collections in academic libraries, several items intended for school or public library collection management deserve mention because they offer particularly useful information or viewpoints. Gillespie and Folcarelli’s (1998) Guides to collection development for children and young adults is an excellent if dated annotated bibliography of selection tools for children's collections. Its strength is annotating many specialized bibliographies which might be useful to a librarian who needs to identify books that support particular needs such as children's literature for math teachers. Baumbach and Miller's (2006) Less is more: a practical guide to weeding school library collections includes guidelines for weeding collections in seventy-one areas; these criteria could also be useful in evaluating which areas of an academic juvenile collection need updating. Academic librarians faced with scarce resources for developing a juvenile literature collection may wish to develop collection improvement plans that target specific curriculum areas each year like those described by Lowe (2001) and Loertscher (1996) for school library collections. In her Beginner's guide to developing school library collections, Kerby (2006) includes a brief but good section on developing a curriculum map with several examples in appendices; her suggestions could be adapted by academic librarians developing juvenile collections to support teacher education programs. 


\section{NEEDS OF EDUCATION STUDENTS}

Although many others may use the collection, such as faculty and staff who have children or local homeschoolers, collection development efforts should focus on supporting teacher education and any other academic programs identified in the collection development policy for juvenile literature. Librarians should begin by reviewing the college's bulletin for majors, teacher certification programs, and courses that are offered. In addition to commonly offered programs such as early childhood, elementary, and various secondary subjects, notice whether the program includes special areas such as deaf education, English as a second language, or guidance counseling. Programs like these may create demand for books with hearing disabled characters and about American sign language, bilingual books, or bibliotherapy or character education books. Some certification programs, such as guidance counseling, may only be offered at the graduate level, so both the undergraduate and graduate bulletin should be consulted for a complete list of programs.

Next, the librarian might look for information about how faculty expect students to use juvenile literature. Since faculty are always busy and education faculty who supervise student practicums often find scheduling meetings particularly difficult , the librarian should check department websites and course management programs like Blackboard and Moodle for syllabi, assignment instructions, and recommended reading lists for education courses. Whenever possible, the librarian should talk with faculty about how they use juvenile literature in teaching. Some questions to ask faculty include:

- $\quad$ How do you use children's and young adult books when teaching?

- What assignments do you give that require students to use juvenile books?

- $\quad$ Do students need juvenile books for classroom experiences and practicums?

- $\quad$ Do you have a list of recommended books that you would be willing to share?

- $\quad$ Would you be willing to share a copy of your syllabus?

- Do your textbooks include lists of recommended books? May I copy those lists? 
- $\quad$ Are there assignments you don’t make because the library doesn’t have juvenile literature to support them?

- $\quad$ Have you noticed any specific weak areas in the juvenile collection?

If it is not possible to talk with faculty in depth, the librarian can ask if they are willing to email documents such as book lists they have prepared for students or syllabi that provide clues to how juvenile literature is used.

The children's literature course, which may be taught in the education or the English department, is probably not the only one that requires students to use juvenile literature. For example, since the National Council of Teachers of Mathematics (NCTM) encouraged using children’s books to help students develop skills in communicating about math concepts in national standards published in 1989 and 2000 (Grover, Monroe, and Jacobs, 2007; National Council of Teachers of Mathematics 1989; National Council of Teachers of Mathematics 2000), faculty may expect students to demonstrate the use of children's literature in courses on teaching methods for mathematics. Many colleges offer courses on reading in the content areas, which may require students to develop lists of books that complement specific units in math, science, art, social studies, and other subjects.

Librarians may also want to scan curriculum standards and frameworks to develop an understanding of the K-12 curriculum. National and state curriculum standards and frameworks describe the topics to be taught at each grade level; Developing Educational Standards includes links to many state and national curriculum standards (Hill 2007). Teacher education students learn to develop instructional activities that address curriculum standards, so the juvenile collection should include titles that support the standards most commonly used by the college's education faculty. Some standards documents include teaching suggestions with book titles; for example, the Mississippi Social Studies Framework (Mississippi Department of Education 2004) suggests introducing the economics concept “opportunity cost” to second graders with Judith Viorst's Alexander Who Used to be Rich Last Sunday. Busy librarians may feel intimidated at the prospect of 
reading long standards documents, but it doesn’t take long to scan relevant standards documents for book titles and an idea of which subjects are covered at various grade levels.

The college bookstore is another source of information. Ask the textbook manager about texts for children's literature and reading in the content area. These texts usually include reading lists which are useful for retrospective collection development and as checklists for evaluating the collection.

Although circulation, in-house use, and interlibrary statistics can provide valuable clues to what areas of the juvenile collection are heavily used and what needs are not being met by the collection, librarians should use them cautiously. Although academic library juvenile collections are usually intended primarily for the support of the teacher education program, the use and interlibrary loan statistics may reflect a substantial amount of nonacademic use. Students, faculty, and staff may borrow materials for home-schooling, to help with their children's school assignments, and for entertainment. Movie releases based on popular juvenile books like Maurice Sendak’s Where the Wild Things Are or Stephanie Meyer’s Twilight may create a sudden demand for the book. Librarians with limited budgets for juvenile literature should focus on supporting the education program and any other academic programs identified in the collection policy.

\section{SOME CHARACTERISTICS OF JUVENILE LITERATURE}

Academic librarians responsible for developing juvenile collections may find some of the terminology used in book reviews and other selection tools confusing. While selection tools for college libraries usually describe the appropriate audience for a book with terms such as general, undergraduate, graduate, community college, or professional, juvenile books may describe audience in terms of age, grade level, reading level, or some combination of these terms. Descriptions of audience in juvenile books can be confusing because reviewers usually try to address both interest level and reading level.

Future teachers, particularly early education and elementary education majors, learn to select books that children can read independently at different stages as well as books that are appropriate for the teacher to read aloud. Understanding the difference between interest levels and reading levels is crucial to developing a 
collection that supports future teachers. Reading level indicates the age range or grade level at which a child can usually read a book without help; reading levels reflect vocabulary, sentence structure, and paragraph complexity. Interest level describes the ages or grades when a child is typically interested in the subject matter of a book; it also may reflect the depth of content and the amount of background knowledge a child needs to comprehend it.

Consider the interest levels and reading levels of picture books. Picture books are commonly thought of as books for young children. But while most picture books do interest young children, they are often too difficult for them to read. A study of Caldecott Medal picture books found that the average reading level was grade 4.75 (Chamberlain 1999), while a random sample of picture books selected from a public library collection ranged from first to seventh grade reading levels (Hunt 1978). The librarian developing the juvenile collection should be aware that the term picture book describes a book in which the pictures and text are equally important, not necessarily a book that a child can read independently.

The terms beginning reader and emerging reader are often used to describe a child learning to read independently or a book suitable for such a child. Barstow, Riggle, and Molnar (2008) described beginning readers as "intended for children from kindergarten to third grade. They usually have a standard format and appear in series, have large print, short sentences, and a limited amount of text per page.” These books may also have a controlled vocabulary. Some review sources will list specific reading levels, often abbreviated RL. Since the age and grade levels indicated in juvenile book reviews generally indicate interest level, selectors looking for books that are suitable for a young child to read independently must be alert for terms like beginning reader, emerging reader, and reading level. Other phrases used to indicate readability are struggling reader, which is often used in reviews to indicate a book that is fairly easy in comparison to its interest level, and high/low or high interest low vocabulary, which is used to describe a book written for older children or young adults who are still learning to read. 
Academic librarians who are unfamiliar with terms used to describe children by age and grade range are likely to find interest level notes almost as confusing as reading levels. Interest levels can be indicated by age ranges, grade levels, or broad terms describing stages of education. Some common terms are:

Preschool: Ages birth to 5

Primary: Ages 5-8, grades 1-3

Intermediate: Ages 8-11, grades 3-6

Elementary: Ages 6-12, grades 1-6

Middle School: Ages 10-13, grades 5-8

Junior High: Ages: 12-14, grades 7-9

High School: Ages 14-19, grades 9-12

Secondary: Ages 12-19, grades 7-12

Young Adult: Ages 12-19, grades 7-12

Interest level designations overlap and are not consistently defined. For example, some review sources consider would put books for kindergarten students in the preschool category while others would put them in the primary category.

Other terms that the juvenile book selector needs to know are wordless book, chapter book, trade book, big book, board book, pop-up book, and toy book. A wordless book is one where the story is told entirely through pictures; teachers use wordless books to help children learn pre-reading skills like sequencing events from beginning to end. Education faculty and students may use chapter book to indicate that they do not want a picturebook; chapter books may be illustrated but the text is usually predominant. Similarly, trade books are books generally sold to the public, not textbooks or other books developed primarily for instructional purposes. Big books are large versions of picturebooks designed for shared reading; they are usually 18 inches high and corresponding wide so students can read the words from several feet away. Board books have thick cardboard pages which preschoolers can turn easily. Pop-up books and toy books have 
movable parts, with paper that opens into three-dimensions as pages are turned or with parts that children lift or turn; they often require special handling in libraries because they are easily damaged.

\section{TIPS FOR DEVELOPING THE JUVENILE COLLECTION}

Developing a collection that supports teaching and learning requires an understanding of user needs, an awareness of existing collection strengths and weaknesses, and a plan to update the collection so that weaknesses are addressed. Methods for identifying user needs were discussed earlier, so the next question is how that information can be organized to guide selection. One possibility is to create a collection planning chart, similar to the budgeting and collection mapping charts discussed by Lowe (2001) and Loertscher (1996). A sample collection planning chart is shown in Figure 1. (See p. 25)

The example in Figure 1 is for a college with majors in early childhood, elementary, and special education (generic and hearing handicapped); certification programs in middle and high school English, social studies, math, and science; and master's programs in elementary education and reading. The chart's rows correspond to school levels, while the columns are divided into broad subjects. The percentage below each subject indicates the proportion of the budget the librarian plans to spend in each area. These percentages may change from year-to-year; for example, this year the librarian plans to address a need expressed by both special education and reading faculty by devoting more funding than usual to books for beginning readers and struggling older readers . Some cells are grayed out, indicating that materials are not needed, while comments have been entered in other cells as reminders of particular needs. Creating or updating a chart like this each year serves several purposes; it helps the librarian plan, can be used to tally books by category as they are selected to help the librarian see how well the plan is being implemented, and, if used as a tally sheet, can be the source of statistics for collection development reports.

Once needs have been identified and collection goals for the year established, the librarian is ready to begin selecting titles. Librarians can choose from many excellent selection sources for juvenile literature, some of which are described in the last section of this paper. If the plan simply calls for updating the current 
collection with new titles, the librarian may wish to do most selection from current review journals. Since not all books are reviewed, selectors will probably also use other sources to identify titles for specific needs. For example, the author's library collects juvenile books by Kansas authors and about Kansas because the state K12 curriculum includes state history and culture; the Kansas Library Association mailing list and Kansas Center for the Book website are useful in identifying authors and titles that major review sources may have missed. Using current review journals allows the librarian to spread selection over the year and helps keep the collection current.

Librarians with limited budgets and many collection development responsibilities may prefer to rely on several of the annual recommended book lists for selection. Using a combination of award lists and both general and subject-oriented notable book lists allows the librarian to focus on selection once or twice a year and take advantage of the collective judgment of other librarians. Relying on annual recommended lists does have disadvantages, including not adding new titles as publisher marketing efforts create demand, missing regional interest titles, and greatly reducing the number of titles considered.

Librarians may also wish to use retrospective sources to improve weak areas of the juvenile collection. Even the best funded and most carefully developed juvenile collection has weak areas as new programs and faculty lead to new needs in areas that have been low priority. In the sample collection development plan outlined in Figure 1, a substantial portion of the budget is being allocated for beginning readers, high interest low vocabulary books, and adult literacy titles because faculty have expressed a need for more of these titles. In this situation, the librarian will probably wish to identify one or more specialized bibliographies, such as those listed at the end of this paper, to identify older titles that will fill gaps in the collection.

Textbooks and teaching methods books can also be used to find titles to fill collection gaps.

Textbooks used in children's literature, reading in the content areas, and teaching methods classes often include lists of recommended books. The library may also have teaching methods books, with sample lessons and units for teachers; some of these books will include bibliographies of recommended titles. 


\section{TIPS FOR ASSESSING THE JUVENILE COLLECTION}

Periodically, the juvenile collection manager will need to assess the collection. While faculty and student feedback are important, as Nevins (1994) found, dissatisfaction with the juvenile collection can stem from difficulty in locating materials for specific purposes rather than the actual titles available. Multiple assessment methods provide more information that interviews and surveys alone can, so the librarian should consider statistical reports and list checking as other methods of collection assessment.

While most integrated library systems (ILS) can provide collection statistics such as number of titles by subject classification, age of titles by classification, and circulation by classification and age of titles, a thorough evaluation of the juvenile collection in an academic evaluation includes assessing support for teaching subjects at different grade levels. Both the level of detail used when cataloging juvenile materials and the flexibility of the ILS reporting system affect whether reports by age/grade level and subject will be available from the ILS. Cataloging records include audience information in the fixed fields; possible audience codes for juvenile literature include:

j Juvenile (Children from birth to grade 9)

a $\quad$ Preschool (Children up to but not including kindergarten)

b Primary (Children from kindergarten to third grade)

c Elementary/Junior High (Children grades 4-8)

d Secondary/Senior High (Children grades 9-12)

The subject classification scheme used also affects the usefulness of ILS reports for juvenile collection assessments; Frierson-Adams (2001) found that academic libraries differ in how they organize juvenile materials. Academic libraries may classify juvenile materials using the Dewey Decimal System, the Library of Congress PZ classification, the full Library of Congress classification with a location code for juvenile materials, or locally developed schemes. If all juvenile titles are classified under PZ, it may be impossible to extract reports by subject. When planning a juvenile collection assessment, the juvenile collection librarian 
should consult with a cataloguer about the audience codes and subject classification schemes used to determine what information can be extracted from the ILS. If the more detailed audience codes have been used consistently and a subject-oriented classification has been used, it may be possible to extract collection reports for assessing support for teaching subjects at different grade levels.

Statistical reports can be useful for analyzing how the quantity of titles supporting different subject and grade levels, the currency of the collection, and usage of the collection. Charting these statistics can help the librarian identify strengths and weaknesses, such as a lack of current science books at the primary level. If statistical reports by grade level and subject cannot be obtained from the ILS, the librarian may need to identify a sample of titles and examine each individually to create a statistical profile of the collection by grade and subject; the collection planning chart in Figure 1 can be adapted to tally sample data. But librarians may also wish to use list-checking to assess collection quality.

List-checking assessments begin with the selection of an appropriate list of recommended titles; the last section of this paper includes some lists the librarian might consider. Librarians can select core collection lists to assess the entire juvenile collection or reader's advisory lists to assess specific portions of the collection like beginning readers or multicultural books. If the collection has few titles from the list, the librarian may decide to use the list as a selection tool for improving the collection. But academic librarians using recommended collection lists for juvenile literature to evaluate collections or select titles should remember that these lists are usually constructed to meet the needs of school and public libraries that serve children, not academic libraries that serve education students. To illustrate the difference, a collection serving elementary children might need a complete series of books about states to meet the demands of the ubiquitous fifth grade state reports assignment. An academic library, on the other hand, is unlikely to see an entire class of students needing books for state reports; it is more likely to need books on many topics at many grade levels for an elementary social studies teaching methods class with every student developing a unit on a different social studies topic. Given this difference in needs, the academic librarian should recognize that not having all the state books recommended in a core collection list does not indicate a weakness in the collection. 
The academic juvenile collection may not need any state books or it may need books about one or two states from several series aimed at different grade levels. Recommended title lists are useful, but they are not a substitute for professional judgment based on knowledge of education faculty and student needs.

Although list-checking is time-consuming, librarians should undertake two list-checking assessments on a regular basis. First, most academic juvenile collections need a strong collection of award-winning titles since students in children's literature classes are often assigned to read these titles. Most American academic librarians will want to check the Caldecott and Newbery Award lists; many will also want to check other award lists. The second list-checking assessment to conduct periodically is for controversial juvenile books, such as titles that appear on the American Library Association's (ALA) Frequently Challenged Books lists (American Library Association 2009). Many, but not all, frequently challenged books are juvenile titles. Librarians should add challenged juvenile titles to the collection as challenges are reported in the media if possible, since these controversial titles tend to be in high demand as education students learn about reasons parents challenge books and methods of responding to challenges. As a quick comparison of the ALA's Frequently Challenged Books lists shows, titles often continue to be controversial for years; the most frequently challenged book of 1990-99, Scary Stories by Alvin Schwartz, was also among the ten most frequently challenged books of 2008. Even if the library has major juvenile award winners on standing order and the librarian consistently order titles as challenges are reported in the media, the librarian should plan to check the collection for these titles every few years since these high-demand books can wear out, be lost, or be stolen.

Librarians may also wish to do list-checking assessments using recommended book lists distributed by faculty and book lists in assigned education textbooks. Students are likely to look for these books, so having a high proportion can reduce student frustration. When using faculty lists, the librarian should be aware that these lists are sometimes based on the library's collection, so they may not include many books the faculty member would like students to read. List-checking can be a time-consuming activity, so the librarian with many lists to check may wish to tactfully inquire whether student workers are available to assist. The 
author has found that in some academic libraries, the circulation supervisor is happy to have student workers assist with such projects as long as the librarian understands the work will be done during slow periods at public service desks.

\section{SELECTION AND EVALUATION TOOLS}

Many excellent selection and reader's advisory tools for juvenile literature are available. This section includes a variety of respected and widely available tools, but many more can be identified by searching WorldCat for subjects such as:

$$
\begin{aligned}
& \text { Children's literature, American -- Bibliography } \\
& \text { Children -- Books and reading -- Bibliography } \\
& \text { Young adult literature -- Bibliography } \\
& \text { Ecology -- Juvenile literature -- Bibliography } \\
& \text { Science -- Juvenile literature -- Bibliography } \\
& \text { Children's literature in mathematics education } \\
& \text { Multiculturalism -- Juvenile literature -- Bibliography }
\end{aligned}
$$

\section{Book Reviews}

Booklist. Reviews books suitable for public and school libraries, about half of each issue is juvenile literature. Only recommended titles are included. Starred reviews indicate outstanding titles. Beginning in 2009, Book Links, which had been a separate journal, became a quarterly supplement; its thematic bibliographies are useful for identifying titles on specific curriculum topics.

Bulletin of the Center for Children’s Books. Reviews titles for preschool through junior high. Starred reviews indicate outstanding titles.

Horn Book Magazine. Reviews children’s books. Books are screened for quality before reviewers are assigned so most reviews are favorable.

School Library Journal. About half of each issue is reviews. Starred reviews indicate outstanding titles. 
VOYA: the Voice of Youth Advocates. Focus is young adult books. About half of each issue is reviews. Each review includes a rating for quality and one for potential popularity.

ALAN Review. Highly selective reviews of young adult titles by the National Council of Teachers of English.

Appraisal: Science Books for Young People. Reviews science and mathematics books, preschool to high school. Each book is reviewed by both a librarian and a scientist.

Bulletin of the Council on Interracial Books for Children. Reviews books depicting minorities. Reviewers are members of the minority group depicted .

\section{Awards}

Newbery Medal (Association for Library Service to Children). Awarded annually since 1922 for best contribution to American literature for children.

Caldecott Medal (Association for Library Service to Children). Awarded annually since 1938 to the illustrator of the best American picture book for children.

Batchelder Award (Association for Library Service to Children). Awarded annually since 1968 to the publisher of the best children's book originally published in a language other than English outside the United States and subsequently translated into English for publication in the United States.

Pura Belpré Award (Association for Library Service to Children). Award since 1996 to the Latino/Latina author and illustrator whose work best portrays Lation cultural experience in a work for children. Separate awards given for narrative and illustration.

Geisel Award (Association for Library Service to Children). Awarded annually since 2006 to the author and illustrator of the best American book in English for beginning readers.

Robert F. Sibert Informational Book Award (Association for Library Service to Children). Awarded annually since 2001 to the author and illustrator of the best informational book published in English.

Laura Ingalls Wilder Award (Association for Library Service to Children). Awarded since 1954 to an author or illustrator whose books, over a period of years, have made a substantial contribution to children's 
literature. Originally given every five years; currently given every two years. The award is given to an author or illustrator for a body of work, not a specific title, so no honor titles are named.

Coretta Scott King Award (American Library Association). Awarded annually since 1970 to African American authors and illustrators for the best book on the African American experience. Separate awards given for narrative and illustration. The John Steptoe Award is also given to recognize excellence in new authors and illustrators.

Schneider Family Book Award (American Library Association). Awarded annually to author or illustrator for best book about disability experience. Three awards are given, for ages 0-8, ages 9-13, and ages 14-18. The books must portray some aspect of living with a disability or with the disability of a family member or friend. The disability may be physical, mental, or emotional. Titles may be fiction or informational.

Printz Award (Young Adult Library Services Association). Awarded annually since 2000 to a book of literary excellence for young adults, ages 12 through 18. The book may be fiction, nonfiction, poetry, or anthology. The author may be of any nationality.

Asian/Pacific American Award for Literature (Asian/Pacific American Librarians Association). Awards given in picturebook and youth categories, for books by or about Asian Pacific Americans.

American Indian Youth Literature Awards (ALA/American Indian Library Association). Presented annually since 2006 to the best book by and about American Indians. Awards are made in three categories: picture book, middle school, and young adult.

Orbis Pictus Award for Outstanding Nonfiction for Children (National Council of Teachers of English). Given annually since 1990; up to five honor books are also named.

Margaret A. Edwards Award. (Young Adult Library Services Association). Awarded annually since 1988 to an author for contributions over time to young adult literature. The award citation recognizes specific titles which meet the award criteria. 


\section{Annual Recommended Book Lists}

ALSC Notable Children’s Books (Association for Library Service to Children). Selected from books published in the United States for children through age fourteen. Automatically includes Newbery medal and honor, Caldecott medal and honor, Batchelder Award, Sibert medal and honor, Belpré medal and honor, and Geisel medal and honor books. The list is typically 60-70 books.

Alex Awards (Young Adult Library Services Association). Selected adult books with special appeal to young adults, ages 12 through 18. Limited to ten titles per year.

Best Books for Young Adults. (Young Adult Library Services Association). Selected and annotated fiction and nonfiction, of acceptable literary quality, with proven or potential appeal to young adults. The list automatically includes the Printz award and honor titles.

Great Graphic Novels for Teens. (Young Adult Library Services Association). Recommended graphic novels and illustrated nonfiction for ages 12-18,

Notable Social Studies Trade Books for Young People (National Council for the Social Studies). Published annually as an insert to the May/June issue of Social Education; also available for a small fee from the Children's Book Council with previous year lists linked from www.cbcbooks.org. Brief annotations include grade ranges from primary through high school and indicate which of the ten thematic strands of the NCSS Curriculum Standards for Social Studies the title supports. Fiction, poetry, folktales, and informational books are included. Since social studies includes human culture, this list is also helpful in selecting art and music resources. The list typically includes 130-150 titles.

Outstanding Science Trade Books for Students K-12 (National Science Teachers Association). Published annually in the March issues of Science and Children, Science Scope, and The Science Teacher; also available for a small fee from the Children’s Book Council and linked from www.cbcbooks.org. Brief annotations include grade ranges from primary (grades K-2) through advanced (grades 9-12) and indicate which of the seven National Science Content Standards the title supports. Informational titles only. The list typically includes 30-40 titles. 


\section{Tools for Specific Subjects/Themes}

\section{Beginning Readers/High Interest Low Vocabulary}

Beyond picture books: subject access to best books for beginning readers. $3^{\text {rd }}$ ed. By Barbara Barstow, Judith Riggle, and Leslie Molnar. Westport, Conn.: Libraries Unlimited, 2008.

High/Low Handbook: Best Books and Web Sites for Reluctant Teen Readers. $4^{\text {th }}$ ed. By Ellen Libretto and Catherine Barr. Westport, Conn.: Libraries Unlimited, 2002.

\section{Controversial Books}

Hit List: Frequently challeged books for children. By Donna Reidy Pistolis. American Library Association, 1996.

Hit list for children 2: frequently challenged books. By Beverley C. Becker and Susan M. Stan. Chicago: American Library Association, 2002.

Hit list: frequently challenged books for young adults. By Merri M Monks and Donna Reidy Pistolis. American Library Association, 1996.

Hit List for Young Adults 2: Frequently Challenged Books. By Teri S. Lesesne and Rosemary Chance. American Library Association, 2002.

Frequently Challenged Books. American Library Association. http://www.ala.org/ala/issuesadvocacy/banned/frequentlychallenged/index.cfm Mathematics

Read any good math lately?: children's books for mathematical learning, K-6. By David J. Whitin and Sandra Wilde. Portsmouth, NH: Heinemann, 1992.

It's the story that counts: more children's books for mathematical learning, K-6. By David J. Whitin and Sandra Wilde. Heinemann, 1995.

Math through children's literature: Making the NCTM standards come alive.By Kathryn L. Braddon, Nancy J. Hall, and Dale Taylor. Teacher Ideas Press, 1993. 


\section{Multicultural}

Children and young adult literature by Latino writers: a guide for librarians, teachers, parents, and students. Worthington: Linworth Publishing, 2002.

Black authors and illustrators of books for children and young adults: a biographical dictionary. $3^{\text {rd }}$ ed. / Barbara Thrash Murphy. New York: Garland, 1999.

Many peoples, one land: a guide to new multicultural literature for children and young adults / Aletha K. Helbig, Agnes Regan Perkins. Westport, Conn.: Greenwood Press, 2001.

Science

Literature-Based science children's books and activities to enrich the K-5 curriculum. By Christine Roots Hefner and Kathryn Roots Lewis. Oryx, 1995.

Butzow, Carol M., and John W. Butzow. Science through children’s literature: an integrated approach. $2^{\text {nd }}$ ed. Teacher Ideas Press, 2000.

Social Studies

Cultures outside the United States in fiction: a guide to 2,875 books for librarians and teachers, K-9 / by Vicki Anderson. Jefferson, N.C.: McFarland, 1994.

Social studies through children’s literature: an integrated approach. By Anthony D. Fredericks. Libraries Unlimited, 1991.

More social studies through children's literature: an integrated approach. By Anthony D. Fredericks. Teacher Ideas Press, 2000.

\section{Spanish Language}

Recommended books in Spanish for children and young adults, 1996 through 1999 / Isabel Schon. Lanham, Md. : Scarecrow Press, 2000. 
Bilingual children’s books in English and Spanish: an annotated bibliography, 1942-2001. / Doris Cruger Dale. Jefferson, N.C.: McFarland, 2003.

\section{Tools by Age/Grade}

Wilson’s Catalogs/Core Collections. These core collections are selected by advisory committees composed of experienced juvenile literature specialists. Each volume includes 6,000-8,000 titles with an additional 2,000-2,400 titles added annually. Entries include subject headings and excerpts of book reviews. Titles include:

Children's Catalog. $19^{\text {th }}$ ed. New York: H.W. Wilson, 2006. Annual paper supplements 2007-2009. Also available online in WilsonWeb as Children's Core Collection.

Middle and Junior High School Catalog. $10^{\text {th }}$ ed. New York: H.W. Wilson, 2009. Annual paper supplements 2010-2012. Also available online in WilsonWeb as Middle and Junior High Core Collection.

Senior High Core Collection. $17^{\text {th }}$ ed. New York: H.W. Wilson, 2007. Annual paper supplements 2008-2010. Also available online in WilsonWeb.

Best Books series. These reader’s advisory guides include about 15,000 titles each. Both fiction and nonfiction are included. Entries include brief annotations and review citations. Titles include:

Best books for children: preschool through grade 6 / John T. Gillespie. $7^{\text {th }}$ ed. Westport, Conn.:

Libraries Unlimited, 2003. Note that a new edition co-authored by Catherine Barr is forthcoming in 2010.

Best books for middle and junior high school readers, grades 6 to 9. $2^{\text {nd }}$ ed. By Catherine Barr and John T. Gillespie. Westport, Conn.: Libraries Unlimited, 2009. 
Best books for high school readers, grades 9-12. By Catherine Barr and John T. Gillespie. Westport, Conn.: Libraries Unlimited, 2009.

A to Zoo: Subject Access to Children’s Picture Books. $7^{\text {th }}$ ed. and supplements. By Carolyn W. Lima and John A. Lima. Westport, Conn.: Libraries Unlimited, 2006. Includes more than 28,000 titles under more than 1,300 subjects. Entries are arranged by author and include subject headings. Indexes by subject, title, and illustrator are included.

Books Kids Will Sit Still For 3: A Read-Aloud Guide. By Judy Freeman. Westport, Conn.: Libraries Unlimited, 2006. The author, an experienced school librarian, selected 1,705 books which children in kindergarten through sixth grade enjoy hearing read aloud. Most of the titles were published from 1995 to 2005; books published before 1995 are included in Books Kids Will Sit Still For and More Books Kids Will Sit Still For. Each annotation includes bibliographic information, suggested grade levels, brief description, teaching idea, related titles, and up to ten subjects. The book includes indexes by author/illustrator, title, and subject.

\section{REFERENCES}

American Library Association. 2009. Frequently challenged books. http://www.ala.org/ala/issuesadvocacy/banned/frequentlychallenged/index.cfm Association of College and Research Libraries. 2009. Guidelines for Curriculum Materials Centers. http://www.ala.org/ala/mgrps/divs/acrl/standards/guidelinescurriculum.cfm.

Barstow, B., Riggle, J., and Molnar, L., eds. 2008. Beyond picture books: subject access to best books for beginning reader. $3^{\text {rd }}$ ed. Westport, Conn.: Libraries Unlimited.

Baumbach, D.J., and Miller, L. L. 2006. Less is more: a practical guide to weeding school library collections. Chicago: American Library Association.

Bay, M. T. 2001. Selecting children’s literature for academic librarians: tips from the trenches. Behavioral \& Social Science Librarian 19: 1-6. 
Bingham, A. 2004.Building a collection of American Indian children's literature at the University of Washington Libraries. Technical Services Quarterly 22: 33-40.

Chamberlain, J., and Leal, D. 1999. Caldecott Medal books and readability levels: not just “picture” books. The Reading Teacher 52: 898-902.

Hill, Charles. 2007. Developing Educational Standards. http://www.edstandards.org/standards.html.

Frierson-Adams, V. 2001. Juvenile collections in academic libraries: survey results and the Ole Miss experience. Mississippi Libraries 65: 117-19.

Gillespie, J.T. and Folcarelli, R. J. 1998. Guides to collection development for children and young adults. Englewood, Colo.: Libraries Unlimited.

Grover, J. M., Monroe, E. E., and Jacobs, J.S. 2007. From peasant to princess: a standards conversion story with a twist. Children's Literature in Education 38: 71-86.

Hirsch, E. G. 2006. On becoming a children's literature librarian in an academic library. OLA Quarterly 12: 23.

Hunt, A. P., and Reuter, J. R. 1978. Readability and children’s picture books. The Reading Teacher 32: 23-27.

Kerby, M. 2006. Collection development for the school library media program: a beginner's guide. Chicago: American Association of School Librarians.

Lare, G. A. 2004. Acquiring and organizing curriculum materials: a guide and directory of resources. 2nd ed. Lanham, Md.: The Scarecrow Press, Inc.

Loertscher, D. V. 1996. Collection mapping in the LMC: Building access in a world of technology. Castle Rock, Colo.: Hi Willow Research and Publishing.

Lowe, K. R. 2001. Resource alignment: providing curriculum support in the school library media center. Knowledge Quest 30: 27-32.

Mississippi Department of Education. 2004 Social Studies Framework. http://www.mde.k12.ms.us/acad/id/Curriculum/ss/frame.html. 
National Council for Accreditation of Teacher Education. 2009. About NCATE. http://www.ncate.org/public/aboutNCATE.asp.

National Council of Teachers of Mathematics. 1989. Curriculum and evaluation standards for school mathematics. Reston, VA: The Council.

National Council of Teachers of Mathematics. 2000. Principles and standards for school mathematics. Reston, VA: National Council of Teachers of Mathematics.

Nevin, S. 1994. Evaluating the children's literature collection: a college library's experience. Collection Management 19: 127-33.

Osa, J. 2003. Collection development: curriculum materials center. The Acquisitions Librarian 30: 131-53.

Rice-Lively, M. L., and Immroth, B. L. 1993. Readers' advisory in the academic library children's collection. Collection Building 12: 63-6.

Uhl, J. O. 2007 The curriculum materials center: library support for a teacher education program. Collection Building 26: 44-47. 
Figure 1: Sample Collecting Plan for Juvenile Literature

\begin{tabular}{|c|c|c|c|c|c|c|}
\hline & Math & Science & Social Studies & Literacy & Fiction & Other \\
\hline & $5 \%$ & $15 \%$ & $15 \%$ & $25 \%$ & $30 \%$ & $10 \%$ \\
\hline $\begin{array}{l}\text { Primary } \\
\text { Gr. K-3 } \\
\text { Ages 5-8 }\end{array}$ & $\begin{array}{l}\text { all math } \\
\text { topics }\end{array}$ & $\begin{array}{l}\text { all science } \\
\text { and health } \\
\text { topics }\end{array}$ & $\begin{array}{l}\text { all social studies } \\
\text { topics }\end{array}$ & $\begin{array}{l}\text { Need wordless } \\
\text { books, and books } \\
\text { for beginning } \\
\text { readers with } R L<1 \text {, } \\
\text { RL 1.0-1.9, and RL } \\
2.0-2.9\end{array}$ & \multirow{4}{*}{$\begin{array}{l}\text { Strong } \\
\text { collection, } \\
\text { maintain by } \\
\text { adding } \\
\text { recent } \\
\text { books at all } \\
\text { grade levels }\end{array}$} & \multirow[t]{2}{*}{$\begin{array}{l}\text { Need books on } \\
\text { deafness. Need } \\
\text { art and music } \\
\text { books. }\end{array}$} \\
\hline $\begin{array}{l}\text { Intermediate } \\
\text { Gr. 3-6 } \\
\text { Ages 8-12 }\end{array}$ & $\begin{array}{l}\text { all math } \\
\text { topics }\end{array}$ & $\begin{array}{l}\text { all science } \\
\text { and health } \\
\text { topics }\end{array}$ & $\begin{array}{l}\text { all topics, } \\
\text { especially Kansas } \\
\text { history }\end{array}$ & nothing needed & & \\
\hline $\begin{array}{l}\text { Middle/Jr. High } \\
\text { Gr. 5-9 } \\
\text { Ages 10-14 } \\
\end{array}$ & $\begin{array}{l}\text { need very } \\
\text { few books }\end{array}$ & $\begin{array}{l}\text { need sex ed } \\
\text { books }\end{array}$ & $\begin{array}{l}\text { all topics, } \\
\text { especially } \\
\text { economics }\end{array}$ & $\begin{array}{l}\text { Need high interest } \\
\text { /low reading level } \\
\text { books, prefer } \\
\mathrm{RL}<4.0\end{array}$ & & \multirow{2}{*}{$\begin{array}{l}\text { Need poetry } \\
\text { books }\end{array}$} \\
\hline $\begin{array}{l}\text { High Sch. } \\
\text { Gr. 9-12 } \\
\text { Ages 14-19 }\end{array}$ & $\begin{array}{l}\text { contest } \\
\text { problem } \\
\text { books } \\
\text { only }\end{array}$ & $\begin{array}{l}\text { science fair } \\
\text { books only }\end{array}$ & nothing needed & $\begin{array}{l}\text { Need high interest / } \\
\text { low reading level } \\
\text { and adult literacy } \\
\text { books, prefer RL } 4.0 \\
5.9\end{array}$ & & \\
\hline
\end{tabular}

